\title{
INCLUSIVE EDUCATION LEARNING IN ELEMENTARY SCHOOLS
}

\section{PEMBELAJARAN PENDIDIKAN INKLUSI PADA SEKOLAH DASAR}

Oleh :

Lia Kurniawati

Politeknik Kridatama

Email : liakurniawati2610@gmail.com

\begin{abstract}
The learning process and the handling of Children with Special Needs (ABK) grade inclusions pinned to the classroom teacher in several schools without teacher inclusion Special Assistants (GPK) the background for this thesis. Theoretically GPK still needed to be able to assist the process of Teaching and Learning Activities (KBM) and according to researchers it will have implications for the management of classroom learning the handling of children with special needs and other students joined in the inclusive classroom. Special Advisors Teacher procurement program has not been met and this is an obstacle. As a first step to determine the problem, the authors examined the inclusive learning management with or without Teacher Special Assistants $(G P K)$ in order to improve the service quality of education both in process and outcome. The implementation are not of cooperation team of child psychologists, pediatricians, neurologists, and psychologists who can contribute greatly to the effectiveness of teaching children with special needs. From the findings of the researchers in the field can provide recommendations that the liveliness of the school component can be improved by following IHT or KKT program organized by the Department of Education so that the provincial level without any GPK implementation of inclusive education learning can be run in accordance with national education goals.
\end{abstract}

Keywords : Inclusive, Learning, Education, Teacher, GPK

Abstrak. Proses pembelajaran dan penanganan Anak Berkebutuhan Khusus (ABK) kelas inklusi ditumpukan kepada guru kelas pada beberapa sekolah inklusi tanpa Guru Pendamping Khusus (GPK) yang melatar belakangi penelitian tesis ini. Secara teoritis GPK tetap dibutuhkan untuk dapat membantu proses Kegiatan Belajar Mengajar (KBM) dan menurut peneliti hal ini akan berimplikasi pada manajemen pembelajaran di kelas terhadap penanganan anak berkebutuhan khusus maupun siswa lainnya yang tergabung dalam kelas inklusif. Pengadaan Guru Pembimbing Khusus belum terpenuhi dan hal ini merupakan kendala. Sebagai langkah awal untuk mengetahui masalah tersebut, penulis meneliti manajemen pembelajaran inklusif dengan atau tanpa Guru Pendamping Khusus (GPK) guna meningkatkan layanan mutu pendidikan baik proses maupun hasil. belum terlaksananya kerjasama tim yang terdiri dari para ahli psikologi anak, dokter anak, dokter neurologi, dan psikolog yang dapat memberikan kontribusi yang besar terhadap efektifitas pembelajaran Anak Berkebutuhan Khusus. Dari hasil temuan dilapangan peneliti dapat memberikan rekomendasi bahwa keaktifan komponen sekolah dapat ditingkatkan dengan mengikuti IHT atau program KKT yang diselenggarakan oleh Dinas Pendidikan tingkat Provinsi sehingga tanpa GPK pun penyelenggaraan pembelajaran pendidikan inklusif dapat berjalan sesuai dengan tujuan pendidikan nasional.

Kata Kunci : Inklusi, Pembelajaran, Pendidikan, Guru, GPK

\section{A. PENDAHULUAN}

Berdasarkan uraian program pembelajaran pada satuan pendidikan yang menyelenggarakan pendidikan inklusif. Dinas pendidikan serta Kelompok Kerja Inklusi yang di bentuk oleh Dinas Pen- didikan Kabupaten Bandung belum bisa memberikan dampak yang optimal terhadap mutu layanan pendidikan, baik ditinjau dari mutu proses maupun hasil pembelajaran.

Beberapa Program dan kegiatan sekolah 
yang dikembangkan dalam mengimplementasikan pendidikan inklusif diantaranya Penyediaan/pengangkatan Guru Pembimbing Khusus, Kerjasama dengan SLB dalam pengadaan Guru Pembimbing Khusus (GPK), Pelaksanaan pendampingan/pembimbingan guru kelas.

\section{Rumusan Masalah}

Peranan Guru Pendamping Khusus (GPK) masih sangat di butuhkan dalam membantu proses pembelajaran yang diselenggarakan sekolah guna optimalisasi proses dan hasil dalam bagi anak yang memerlukan layanan khusus namun selama ini pembelajaran masih mengikuti perencanaan, pelaksanaan dan penilaian pembelajaran secara regular sehingga belum maksimal dalam pengembangan minat, bakat dan potensi dari ABK tersebut. (Keller, 2013)

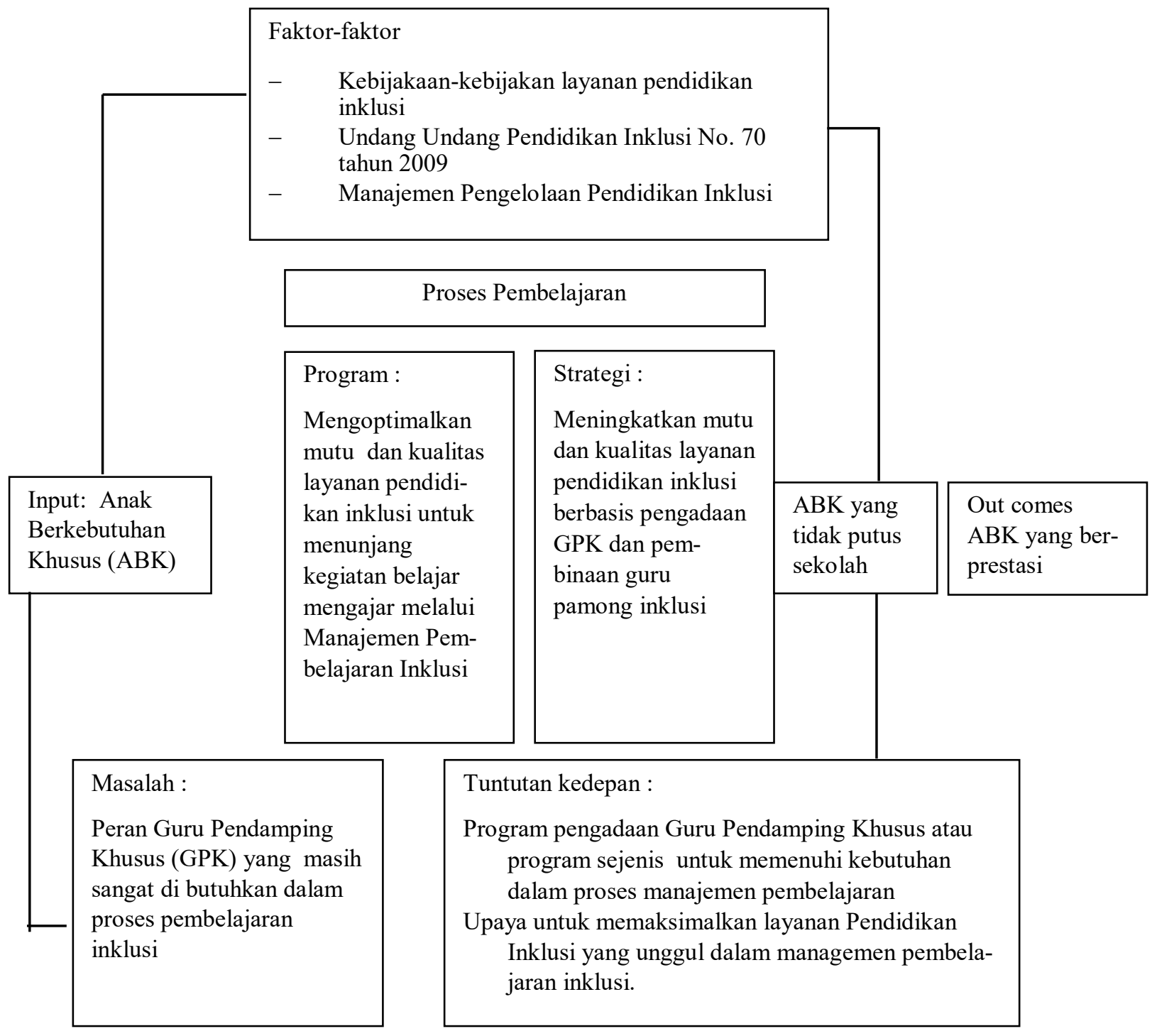

158 Pembelajaran Pendidikan Inklusi Pada Sekolah Dasar 


\section{Batasan masalah}

Mengingat luasnya aspek Manajemen pendidikan pembelajaran inklusi maka penelitian ini membatasi pada pembelajaran Inklusi dengan atau tanpa Guru Pendamping Khusus (GPK) di SD Negeri Rahayu 6 Kecamatan Marga Asih dan SD Negeri Cangkuang 19 Kecamatan Dayeuh Kolot Kabupaten Bandung. Adapun tujuan pembatasan masalah ini Memperoleh gambaran tentang Perencanaan, pelaksanaan, evaluasi, faktor pendukung dan faktor penghambat manajemen pembelajaran dengan atau tanpa Guru Pendamping Khusus (GPK) serta program pembinaan guru kelas sebagai guru pamong inklusi di sekolah dasar yang sesuai dengan mutu proses dan mutu hasil.

Diharapkan memberikan manfaat pada komponen sekolah yaitu bagi siswa, guru, kepala, sekolah dan pengawas. Dengan asumsi guru kelas sebagai ujung tombak pelaksanaan pembelajaran menjadi salah satu kajian menarik dari sekolah reguler inklusi yang berada di Kabupaten Bandung. Berhubung sekolah inklusi belum pernah meluluskan siswa serta masih terkendala dengan pengelolaan manajemen pembelajaran, maka penelitian berfokus pada :

Kegiatan apa yang dilakukan dalam perencanaan, pelaksanaan, Evaluasi, faktor pendukung dan penghambat pembelajaran dengan atau tanpa Guru Pendamping Khusus (GPK). Metode yang dilakukan adalah penelitian lapangan field research dan hasil penelitian kualitatif lebih menekankan makna daripada generalisasi. Pendekatan menggunakan kualitatif dengan teknik Pengamatan (Observasi), Wawancara (Interview), Studi Dokumentasi.

\section{B. HASIL DAN PEMBAHASAN}

Berdasar pada Permendiknas Nomor 41 tahun 2007 tentang standar proses untuk satuan pendidikan dasar dan menengah, bahwa standar proses berisi kriteria minimal proses pembelajaran pada satuan pendidikan dasar dan menengah diseluruh wilayah hukum Negara Kesatuan Republik Indonesia. Standar proses meliputi perencanaan proses pembelajaran, pelaksanaan proses pembelajaran, penilaian hasil pembelajaran dan pengawasan hasil pembelajaran untuk terlaksananya proses pembelajaran yang efektif dan efisien.

Pada pendidikan inklusif dibutuhkan instrument input memadai sebagai penunjang keberhasilan program inklusifitas. Salah satu diantaranya adalah peran profesional dari Guru Pembimbing Khusus (GPK). Guru Pembimbing Khusus (GPK) adalah guru yang ber- 
tugas mendampingi di sekolah penyelenggara pendidikan inklusif dan memiliki kompetensi dalam menangani siswa berkebutuhan khusus. (Kustawan, 2013)

Hal tersebut selaras dengan pernyataan dari Scott (1995) dalam Alimin (2013) bahwa the success of the inclusive education depends, to a large extent, on the willingness and the ability of teachers to make accommodations for individuals with special needs". Scott menegaskan bahwa kesuksesan pendidikan inklusif tergantung pada besarnya keinginan dan kemampuan guru dalam mengakomodasi kebutuhan individu ABK.

Menurut Stainback, 1980 dalam Irawan Sensus, 2013,

Pendidikan inklusif adalah sistem layanan pendidikan yang mensyaratkan anak berkebutuhan khusus belajar di sekolah-sekolah terdekat di kelas biasa bersama teman-teman seusianya. Sekolah penyelenggara pendidikan inklusif adalah sekolah yang menampung semua murid di kelas yang sama. Sekolah ini menyediakan program pendidikan yang layak, menantang, tetapi disesuaikan dengan kemampuan dan kebutuhan setiap murid maupun bantuan dan dukungan yang dapat diberikan oleh para guru, agar anak-anak berhasil
Selanjutnya dalam pendidikan inklusif diperlukan peran serta GPK sebagai center of education yang mempunyai tugas penting dalam pendampingan $\mathrm{ABK}$. Jabaran mengenai tugas GPK dalam pendidikan inklusif terdapat dalam Permendiknas No. 70. Tahun 2009, tugas dan tanggung jawab Guru Pembimbing Khusus (GPK) dalam pembelajaran pada pendidikan inklusif yang meliputi: (1) merancang dan melaksanakan program kekhususan; (2) melakukan proses identifikasi, assesmen dan menyusun program pembelajaran individual; (3) memodifikasi bahan ajar; (4) melakukan evaluasi program pembelajaran bersama guru kelas; dan (5) membuat laporan program dan perkembangan anak berkebutuhan khusus .

Pembelajaran Inklusi dalam Teori Islam, Menuntut ilmu itu dihukumi wajib karena merupakan perintah Tuhan bagi hambanya yang bernama manusia baik laki-laki maupun perempuan sesuai dengan sabda Nabi Muhammad SAW yang artinya: "Menuntut ilmu itu wajib bagi setiap muslim laki-laki dan perempuan" (HR. Bukhari Muslim). Termasuk kategori menuntut ilmu ialah diantaranya melalui proses pendidikan baik formal, informal maupun nonformal.

Al-Qur'an Surat 43 Az-Zukhruf ayat 32 menyebutkan yang artinya "Allah te- 
lah menentukan diantara manusia penghidupan mereka dalam kehidupan dunia, dan Allah telah meninggikan sebagian dari mereka atas sebagian yang lain beberapa derajat agar sebagian mereka dapat saling mengambil manfaat (membutuhkan)". Firman Allah ini menunjuk setiap kita haruslah berfungsi dan bermanfaat bagi makhluk lain

Deskripsi umum mengenai objek penelitian dari SD Negeri Rahayu 6 dan SD Negeri Cangkuang 19 sebagai berikut :

1. SD Negeri Rahayu 6, Sekolah yang sudah terakrediatasi A ini terletak di 2. Jl. Terusan Permai 25 No. 2 Desa Mekar Rahayu Kecamatan Margaasih Kabupaten Bandung.

Merupakan salah satu sekolah pilot project pendidikan inklusi di Kabupaten Bandung, dengan manajemen pendidikan inklusi yang sudah tertata apik di bawah kepemimpinan $\mathrm{Hj}$. Tatis Sribudiarti, S. Pd. yang telah mendapatkan program pendidikan KKT dari dinas pendidikan Provinsi Jawa Barat.

Berbagai prestasi di raih dalam bidang pendidikan inklusi yang mengikut sertakan anak-anak berkebutuhan khusus dalam berbagai lomba kependidikan dan selalu meraih prestasi. Selain itu di imbangi dengan SDM dari guru-guru yang telah mendapatkan pendidikan dan pembinaan di bidang pendidikan inklusi sehingga tidak heran jika sekolah ini selalu dijadikan maket pembelajaran pendidikan inklusi di lingkungan kabupaten Bandung. Dalam workshop sekolah rintisan inklusi, 2013. KKT adalah Kewenangan Kompetensi Tambahan yang dinerdayakan dari sumber daya sekolah dan stake holder dengan melibatkan masayarakat dan dinas terkait.

SD Negeri Cangkuang 19, terletak di Jalan Terusan Sayati Palasari Desa Cangkuang Kulon Kecamatan Dayeuh Kolot Kabupaten Bandung.

Merupakan SD imbas dari sekolah inti di satu gugus, dimana dalam satu gugus tersebut terdapat 7 (Tujuh ) SD. Dibawah kepemimpinan kepala sekolah yang baru Ibu Yeti Sumaryati H. S. Pd., diharapkan sekolah ini mendapat pencerahan baru untuk peserta didik berkebutuhan khusus dimana hal ini merupakan limpahan dari seleksi PPDB di ke enam 6 lainnya.

Hal ini merupakan tantangan baru untuk guru-guru di sekolah tersebut dimana dalam segala keterbatasan fasilitas sarana dan 
prasarana yang ada harus mendidik anak-Anak Berkebutuhan Khusus. Walaupun sekolah belum terakreditasi ini, namun dengan penuh semangat guru-guru di SD Cangkuang 19 ini tetap melaksanakan pendidikan inklusi untuk anak-anak berkebutuhan khusus dengan kategori ringan seperti slow learner, disleksia, disgrafia dan diskalkulia.

SD Negeri Rahayu 6 mempunyai kendala dalam pengadaan Guru Pendamping Khusus (GPK), namun berdasarkan hasil komunikasi dan pembinaan dari tim pokja inklusi Kabupaten Bandung. Kepala Sekolah SD Negeri Rahayu 6 mengikuti program Kependidikan dan Kewenangan Tambahan (KKT) dalam atas rekomendasi dari Dinas Pendidikan Provinsi Jawa Barat. SD Cangkuang 19 memiliki dua kelas membuat sekolah ini mengalami berbagai hambatan dalam pelaksanaan pembelajaran terutama dalam pembelajaran siswa inklusif dan belum pernah meluluskan siswa inklusif karena kendala SDM.

Dua sudut pandang mengenai kebutuhan Guru Pendamping Khusus (GPK) pada sekolah inklusi yakni : Kebutuhan program pembelajaran Anak Berkebutuhan Khusus (ABK) dapat di tutupi dengan berbagai pelatihan guru kelas seperti IHT dan keikutsertaan pendidikan dan pelatihan yang diselenggarakan dinas terkait. (Kurniasanti, 2013). Dengan keikutsertaan guru kelas dalam setiap program pendidikan dan pelatihan diharapkan tidak terjadi kendala dalam pembuatan Program Pembelajaran Individual untuk Anak Berkebutuhan Khusus.

Sudut pandang yang kedua bahwa satuan pendidikan yang baru akan menyelenggarakan pembelajaran pendidikan inklusi memang memerlukan Guru Pendamping Khusus sebagai langkah awal dalam pendampingan peserta didik berkebutuhan khusus hal ini dibutuhkan keaktifan dari seluruh komponen sekolah terutama Kepala sekolah dan guru kelas sehingga akan berdampak pada peningkatan pembelajaran $\mathrm{ABK}$.

Implikasi digunakannya 3 jenis kurikulum pada sekolah inklusif sistem penilaian, instrumen penilaian, analisis hasil penilaian, sistem laporan hasil penilaian, serta simbol penghargaan hasil penilaian, harus disesuaikan dengan jenis kurikulum yang dipergunakan, Implikasi penilaian berdasarkan kurikulum sebagai berikut :

1. Penilaian terhadap $\mathrm{ABK}$ ringan yang mengikuti kurikulum umum/ reguler dapat menggunakan kriteria penilaian reguler sepenuhnya. 
2. Penilaian terhadap $\mathrm{ABK}$ sedang

3. Terhadap ABK berat pada sekolah yang menggunakan kurikulum modifikasi sistem penilaiannya menggunakan perpaduan antara sistem penilaian umum/reguler dan sistem penilaian individual. inklusif yang menggunakan kurikulum yang diindividualisasikan, sistem penilaiannya menggunakan norma penilaian individual yang didasarkan pada tingkat daya serap yang didasarkan pada base line

Tabel 2.1 Ssasaran jenis kurikulum dan implikasi sistem penilaian bagi anak dengan gangguan intelektual

\begin{tabular}{|c|c|c|c|c|c|}
\hline $\begin{array}{c}\text { Sasara } \\
\left.n^{*}\right)\end{array}$ & $\begin{array}{c}\text { Jenis } \\
\text { Kurikulu } \\
\text { m }\end{array}$ & $\begin{array}{l}\text { Sistem } \\
\text { Penilaian }\end{array}$ & $\begin{array}{c}\text { Instrume } \\
\text { n } \\
\text { Penilaian }\end{array}$ & Analisis & $\begin{array}{l}\text { Sistem } \\
\text { Laporan }\end{array}$ \\
\hline $\begin{array}{l}\text { Siswa } \\
\text { umum/ } \\
\text { reguler dan } \\
\text { siswa lambat } \\
\text { belajar }\end{array}$ & $\begin{array}{l}\text { Kurikulum } \\
\text { umum/reguler }\end{array}$ & $\begin{array}{l}\text { Mengikuti sistem } \\
\text { penilaian yang } \\
\text { berlaku di sekolah } \\
\text { reguler tersebut }\end{array}$ & $\begin{array}{l}\text { Menggunakan } \\
\text { instrumen } \\
\text { penilaian yang } \\
\text { di tetapkan } \\
\text { pada Dinas } \\
\text { Pendidikan } \\
\text { setempat }\end{array}$ & $\begin{array}{l}\text { Menggunakan } \\
\text { norma analisis } \\
\text { reguler yang } \\
\text { berlaku di } \\
\text { sekolah } \\
\text { tersebut }\end{array}$ & $\begin{array}{l}\text { Menggunakan } \\
\text { sistem dan } \\
\text { format laporan } \\
\text { yang berlakudi } \\
\text { sekolah } \\
\text { tersebut }\end{array}$ \\
\hline $\begin{array}{l}\text { Siswa } \\
\text { umum/ } \\
\text { reguler dan } \\
\text { tunagrahita } \\
\text { ringan }\end{array}$ & $\begin{array}{l}\text { Kurikulum } \\
\text { umum/reguler } \\
\text { yang } \\
\text { dimodifikasi }\end{array}$ & $\begin{array}{l}\text { Mengikuti sistem } \\
\text { penilaian yang } \\
\text { berlaku di sekolah } \\
\text { reguler tersebut } \\
\text { dengan modifikasi } \\
\text { isi. }\end{array}$ & $\begin{array}{l}\text { Menggunakan } \\
\text { instrumen } \\
\text { penilaian dari } \\
\text { Dinas } \\
\text { Pendidikan } \\
\text { setempat yang } \\
\text { dimodifikasi }\end{array}$ & $\begin{array}{l}\text { Menggunakan } \\
\text { norma reguler } \\
\text { yang berlaku }\end{array}$ & $\begin{array}{l}\text { Menggunakan } \\
\text { format reguler } \\
\text { yang berlaku }\end{array}$ \\
\hline $\begin{array}{l}\text { Tunagrahita } \\
\text { sedang }\end{array}$ & $\begin{array}{l}\text { Kurikulum } \\
\text { umum/reguler } \\
\text { yang } \\
\text { dimodifikasi }\end{array}$ & $\begin{array}{l}\text { Mengikuti sistem } \\
\text { penilaian umum/ } \\
\text { reguler, dengan } \\
\text { modifikasi isi dan } \\
\text { pelaksanaan }\end{array}$ & $\begin{array}{l}\text { Menggunakan } \\
\text { instrumen } \\
\text { penilaian dari } \\
\text { Dinas } \\
\text { Pendidikan } \\
\text { setempat yang } \\
\text { dimodifikasi }\end{array}$ & $\begin{array}{l}\text { Mengacu pada } \\
\text { norma reguler } \\
\text { dan norma } \\
\text { individual }\end{array}$ & $\begin{array}{l}\text { Menggunakan } \\
\text { format reguler } \\
\text { yang berlaku, } \\
\text { delengkapi } \\
\text { dengan } \\
\text { deskripsi naratif } \\
\text { singkat }\end{array}$ \\
\hline $\begin{array}{l}\text { Tunagrahita } \\
\text { berat }\end{array}$ & $\begin{array}{l}\text { Kurikulum yang } \\
\text { diindividuali- } \\
\text { sasikan }\end{array}$ & $\begin{array}{l}\text { Sistem penilaian } \\
\text { individual yang } \\
\text { didasarkan pada } \\
\text { standar base line } \\
\text { daya serap }\end{array}$ & $\begin{array}{l}\text { Instrumen } \\
\text { khusus yang } \\
\text { dibuat oleh } \\
\text { sekolah }\end{array}$ & $\begin{array}{l}\text { Mengacu pada } \\
\text { norma analisis } \\
\text { individual }\end{array}$ & $\begin{array}{l}\text { Menggunakan } \\
\text { format } \\
\text { deskriptif } \\
\text { naratif }\end{array}$ \\
\hline
\end{tabular}


Edutech, Tahun 16, Vol.16, No.2, Juni 2017

*) - Indikator berat ringannya ABK merujuk pada derajat kelainan yang disandang dan relefansinya dengan persentase kurikulum umum yang dapat diikuti, Tingkat berat ringannya kualifikasi peserta didik ditentukan oleh tim ahli sekolah.

Salah satu contoh profil ABK dengan kelainan Hyperaktif Disorder :

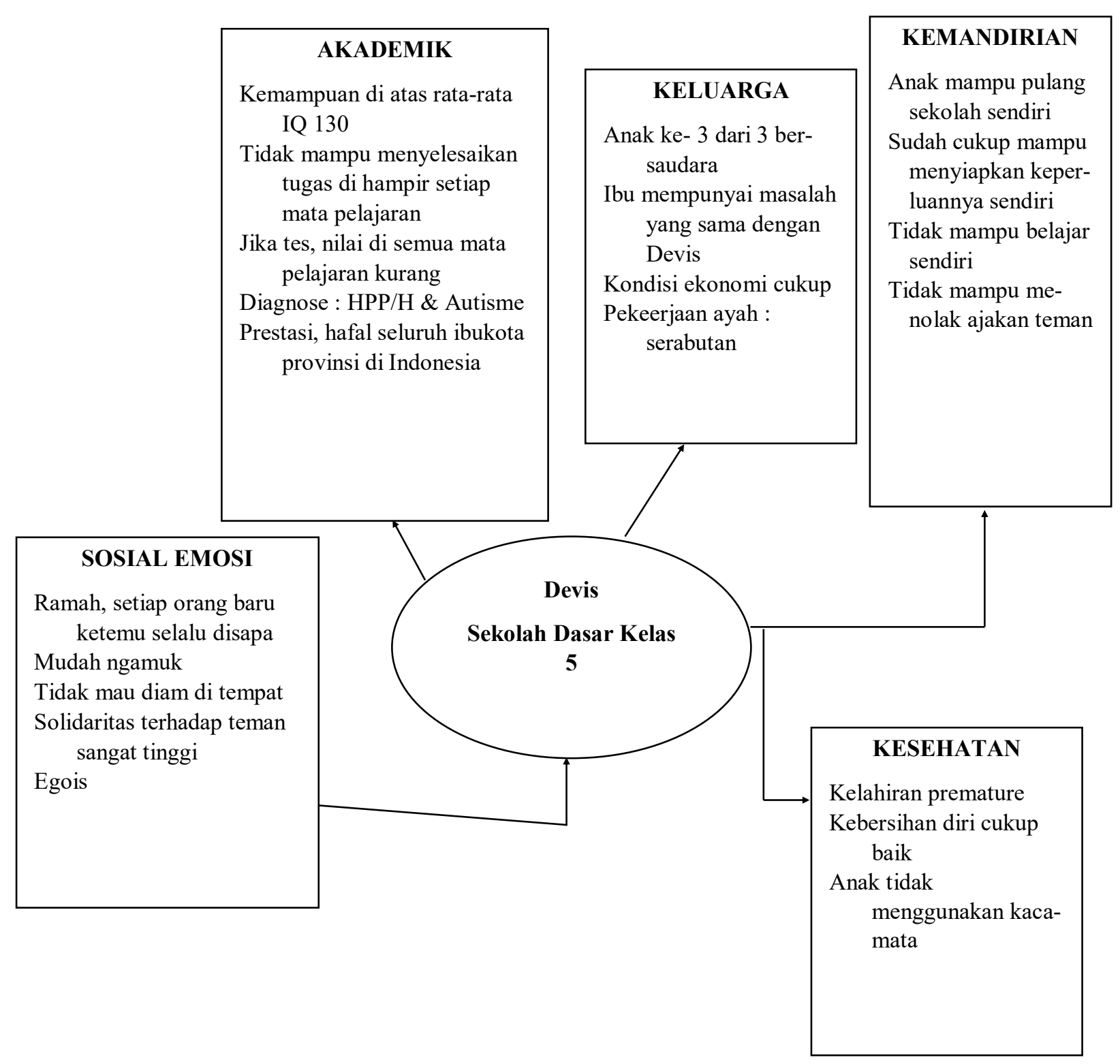

Bagan 2.1 Profil ABK

1. Hyperactive (attention deficit dis- yakit, tetapi suatu gejala atau symptoms orders with hyperactive).

(Bathaw dan Parret, 1986:261 dalam

Hyperactive bukan merupakan pen- PLB FIP UPI). Dimungkinkan terjadi 
bahwa seorang anak mempunyai kelainan in atensi disorder dengan hiperaktif (attention deficit disorder with hyperactive), symptoms terjadi disebabkan oleh faktor-faktor antara lain : brain damage, an emotional disturbance, a hearing deficit dan mental retardation. Dewasa ini banyak kalangan medis masih menyebut anak hiperaktif dengan istilah attention deficit disorder (ADD).

Gejala-gejala kelainan dari anak hiperaktif antara lain: intensi, hiperaktivitas, dan impulsivitas. Anak-anak hiperaktif memerlukan suatu layanan dengan cara pemberian intervensi dengan terapi farmakologi dikombinasikan dengan terapi perilaku (behavior modification). Apabila anak hiperaktif tidak mendapatkan layanan terapi yang adequate, maka anak tersebut di kemudian hari akan berkembang ke arah kriminal, suka mengutil barang, mencuri, mencoba -coba narkoba, merusak property dan cenderung berkembang ke arah problem yang lain, yaitu cinduct disorder (CD).

Ciri yang paling mudah di kenali bagi anak hyperaktif adalah anak akan selalu bergerak dari satu tempat ke tempat lain dan sangat jarang untuk mampu diam selama lebih kurang 5 menit hingga 10 menit guna melakukan suatu tugas kegiatan yang diberikan gurunya. Oleh karena itu, di sekolah anak hiperaktif mendapatkan kesulitan untuk berkonsentrasi dalam tugas-tugasnya, selalu mudah bingung atau kacau pikirannya, tidak suka memerhatikan perintah atau penjelasan gurunya, selalu tidak berhasil dalam melaksanakan tugas-tugas pekerjaan sekolah, sangat sedikit sekali kemampuan mengeja huruf dan tidak mampu untuk meniru huruf-huruf (Rapport dan Ismond, 1984 dalam Bandi:2009)

Definisi mengenai hyperaktif menurut Stewart dalam (Bandi : 2009) sebagai berikut :

“...Hyperactives child syndrome, typically a child with this syndrome is continually in motion, cannot concentrate for more than a moment, acts and speaks in impulse, is impatient and easily upset. At home he is constantly in trouble of his distracted, rarely finishes his work, tend to clown and talk out of turn in class and becomes labeled a discipline problems" (Alimin, 2013)

Ciri-ciri yang sangat nyata berdasarkan definisi tersebut bagi peserta didik hiperaktif adalah sebagai berikut :

a. Selalu berjalan-jalan memutari ruang kelas dan tidak mau diam.

b. Sering mengganggu teman-teman sekelasnya.

c. Suka berpindah-pindah dari satu kegiatan ke kegiatan lainnya, sangat jarang untuk tinggal diam menyelesaikan tugas sekolah dan 
paling lama tinggal diam di tempat duduknya sekitar 5 sampai 10 menit.

d. Mempunyai kesulitan untuk berkonsentrasi dalam mengerjakan tugas-tugas di sekolah.

e. Sangat mudah berprilaku untuk mengacau atau mengganggu.

f. Kurang memberi perhatian untuk mendengarkan orang lain berbicara.

g. Selalu mengalami kegagalan dalam melaksanakan tugas-tugas di sekolah.

h. Sulit mengikuti perintah atau suruhan lebih dari satu pada saat yang bersamaan.

i. Mempunyai masalah belajar hampir di seluruh mata pelajaran, dan sering gagal di sekolah disebabkan inatensi dan masalah belajar karena persepsi visual dan audito- ry yang lemah.

j. Tidak mampu menulis surat, mengeja huruf dan berkesulitan dalam surat menyurat.

k. Oleh karena sering menurutkan kata hati (impulsiveness) mereka sering mendapatkan kecelakaan dan luka.

Kesulitan belajar anak hiperaktif disebabkan pula adanya control diri yang kurang dan sering impulsive dalam setiap kegiatan yang dilakukan, sangat mudah marah dan sering kali suka berkelahi. Ada di antara mereka tidak suka berolahraga karena adanya kekakuan gerak atau kecanggungan, namun perlu di catat bahwa tidak semua anak dengan hiperaktif mempunyai attention deficit disor$\operatorname{der}(\mathrm{ADD})$.

Hubungan antara attention deficit disorder, learning disability dan hyperactive dapat dilihat pada diagram berikut :

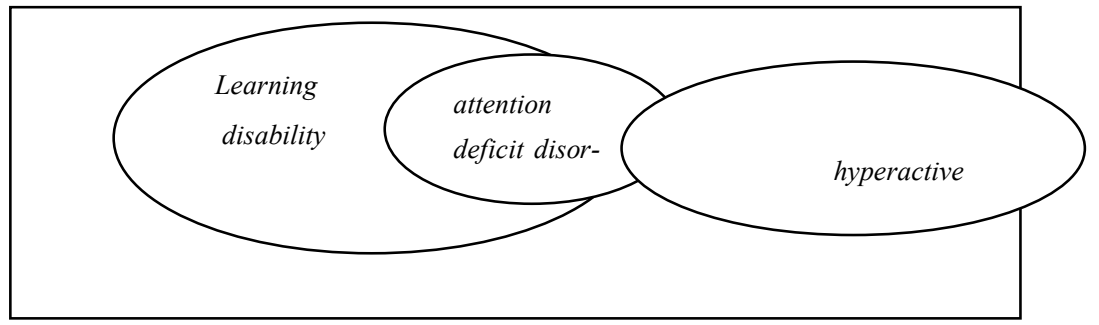

Bagan 2.2 Hubungan antar a attention deficit disorder, learning disability dan hyperactive

Kasus lainnya berkaitan dengan hipe- seperti adanya inatensi, perilaku impulraktif antara lain, sebagai berikut : Anak sive, frustasi dan rendahnya kemampuan tunagrahita dapat juga mempunyai kedalam bidang kognitif, pendekatan secara lainan atau hendaya penyerta hiperaktif, medis dalam kasus semacam ini men- 
galamai pengobatan yang kurang efektif.

Sifat inatensi dan hiperaktif terdapat juga pada anak yang mempunyai seizure disorder. Anak dengan hendaya pendengaran dapat juga mempunyai sifat hiperaktif atau problem perilaku lainnya. Problem ini disebabkan oleh kerusakan pada sebagian sel-sel saraf pada otak atau adanya kesalahan diagnosis. Pada anak dengan kesulitan psikiatri dapat dimungkinkan mempunyai hiperaktif disebabkan oleh adanya perasaan tidak aman pada dirinya atau salah mengenai tanggapan dirinya dan kurang responsivitas terhadap orang lain.

\section{SIMPULAN DAN SARAN}

Berdasarkan deskripsi dan pembahasan hasil penelitian Faktor pendukung penyelenggaraan pembelajaran pendidikan inklusi di SD Negeri Rahayu 6 banyak di antaranya melalui dukungan kebijakan pemerintah dari Dinas Pendidikan Provinsi dan Dinas Pendidikan Kabupaten Bandung. Dalam pelaksanaan pembelajaran ABK sudah di tangani oleh guru yang sudah mendapatkan berbagai pelatihan, pembiayaan penyelenggaraan pendidikan inklusi sudah terpisah dari pembiayaan BOS reguler.

Sedangkan di SD Negeri cangkuang 19 sebanyak $70 \%$ guru ramah terhadap anak berkebutuhan khusus. faktor penghambat di SD Negeri Rahayu 6 yakni orang tua $\mathrm{ABK}$ kurang terlibat dalam pemenuhan kebutuhan pembelajaran siswa ABK, sehingga penanganan ABK sepenuhnya di tumpukan pada pembelajaran yang ada di sekolah. Sedangkan di SD Negeri Cangkuang 19 guru kelas untuk anak berkebutuhan khusus yang kelas lainnya masih membutuhkan pembinaan karena belum meratanya pembinaan, dalam pengembangan kurikulum masih harus di kembangkan terutama dalam pembuatan program pembelajaran individual.

Manajemen pembelajaran inklusi di SD Negeri Rahayu 6 yakni dari skill kepala sekolah yang telah mengikuti program KKT yang di selenggarakan oleh Universitas Pendidikan Indonesia di prakarsai oleh Dinas Pendidikan Provinsi Jawa Barat, selain itu terdapat guru pamong kelas inklusi yang telah mendapatkan pembinaan dan mengikuti berbagai perlombaan kependidikan inklusi. di SD Negeri Rahayu 6 adalah tidak semua guru ramah dan mau membuka diri serta membuka hati untuk berinteraksi dengan peserta didik berkebutuhan khusus, namun hal ini dapat di atasi dengan kemampuan manajerial dari kepala sekolah untuk memberikan pengertian dan penyelenggaraan IHT secara rutin di adakan di sekolah dengan mengundang praktisi-praktisi yang berkompeten di bidang pendidikan inklusi. 
Sedangkan faktor pendukung dalam manajemen pembelajaran inklusi di SD Negeri Cangkuang 19 yakni terdapat guru yang berpendidikan Strata-2 yang sedang melaksanakan penelitian mengenai pembelajaran pendidikan inklusi sehingga bisa lebih aplikatif dalam pembelajaran. Faktor penghambat dalam manajemen pembelajaran inklusi di SD Negeri Cangkuang 19 yakni pembinaan guru pendidikan inklusi tidak merata dan beberapa guru masih belum terbuka dan ramah terhadap anak berkebutuhan khusus.

Belum tersentuhnya pembinaan dari pengawas mengenai pembelajaran pendidikan inklusi. Dengan adanya Peraturan Bupati No. 4 tahun 2004, kebijakan penyelenggaraan pembelajaran pendidikan inklusi sudah dibentuk kelompok kerja (POKJA) pendidikan inklusi tingkat Kabupaten Bandung namun masih dirasa kurang implikatif dalam pelaksanaannya.

Tingkat kecamatan masih kurang implikatif sehingga berdampak dalam pengadaan Guru Pendamping Khusus kurang mendapatkan respon yang progresif dari SLB sehingga berdampak pada pengelolaan pada tingkat satuan pendidikan khususnya pada sekolah-sekolah dasar reguler yang membutuhkan kontribusi dalam pembuatan program pembela- jaran Individual di sekolah reguler dan hal ini menjadi salah satu faktor penghambat untuk sekolah-sekolah dasar yang sudah di wajibkan untuk menerima Anak Berkebutuhan Khusus.

Perencana, pelaksana dan penilai dalam proses pembelajaran pendidikan inklusi Peran serta GPK dalam pembelajaran pendidikan inklusi memang sangat diperlukan keeterlibatannya terutama dalam pembuatan program pembelajaran individual, meskipun dalam pelaksanaan pembelajaran GPK tidak turut langsung menangani ABK. Perencanaan pembelajaran hendaknya di susun pada setiap awal semester dimana dibentuknya tim pengembang kurikulum dengan melibatkan GPK dan tim ahli lainnya dalam menangani $\mathrm{ABK}$ dengan serius, selama ini penanganan $\mathrm{ABK}$ di sekolah dasar negeri masih dirasa kurang maksimal.

Keaktifan kepala sekolah dan pengawas gugus dirasakan belum maksimal dalam pembelajaran pendidikan inklusiterutama di SD Negeri Cangkuang 19, sedangkan kepala sekolah SD Negeri Rahayu 6 sudah sangat memahami dalam pendidikan inklusi sehingga dalam pelaksanaan pembelajaran inklusi dapat dijadikan sebagi rekomendasi penyelenggaraan pendidikan inklusi. pemerataan pembinaan guru pamong inklusi masih dirasakan kurang intensif sehingga hal 
Edutech, Tahun 16, Vol.16, No.2, Juni 2017

ini akan berpengaruh pada proses pembelajaran ABK.

Guru kelas sebagai salah satu ujung tombak pembelajaran, pemerataan pembinaan guru pamong inklusi masih dirasakan kurang intensif sehingga hal ini akan berpengaruh pada proses pembelajaran ABK. Selain itu hendaknya harus memiliki skill dalam menangani anak berkebutuhan khusus sehingga proses pembelajaran dapat berjalan sesuai dengan standar kompetensi lulusan yang diharapkan. Hal ini bisa dilakukan dengan berkoordinasi dengan kepala sekolah dan pengawas gugus tingkat kecamatan apabila keterlibatan GPK masih dirasa kurang memadai.

\section{DAFTAR PUSTAKA}

Agus Irawan Sensus, M.Pd. (2013) Grand Desain Pendidikan Inklusif di Kabupaten Bandung, Satuan Layanan Bimbingan Kemandirian Anak Tunagrahita.

Alimin, Z. (2013). Layanan Pendidikan Inklusif bagi Pelatih, Jakarta: Save the Children IKEA

Delphie, Bandi. (2009). Pembelajaran Anak Berkebutuhan Khusus, Sleman: Intan Sejati Klaten.

Helen Keller Internasional, (2013). Pelatihan Pendidikan Kekhususan bagi Guru Pembimbing Khusus, Jakarta: Direktorat Pembinaan-
PKLK Dikdas Kemdikbud, USAID.

Kurniasanti, I. (2013). Panduan Teknis Pelaksanaan Pelatihan, Prosedur Operasional Standard an Modul Pelatihan Pendidikan Inklusif Berbasis Sekolah, Kementrian Pendidikan dan Kebudayaan Direktorat Jenderal Pendidikan Dasar Direktorat Pendidikan PKLK Dikdas: USAID.

Kustawan, Dedi. (2013). Pembelajaran Yang Ramah, Merancang Pembelajaran Aktif, Inovatif, Kreatif, Efektif \& Menyenangkan Di Sekolah Ramah Anak, Jakarta: Luxima Metro Media.

Moleong, J. (2010). Metodologi Penelitian Kualitatif, Bandung: Alfabeta.

Peraturan Menteri Republik Indonesia Nomor 70 Tahun 2009 Pasal 7

PLB FIP UPI, (2009). Manajemen Pendidikan Inklusif , Jakarta: PLB FIP UPI.

Workshop Direktorat Pembinaan Pendidikan Khusus dan layanan Khusus Dikmen Direktorat Jendral Pendidikan Menengah Kemendikbud, (2012). peningkatan ualitas pembinaan pengelola rintisan sekolah inklusif, Bandung. 